\title{
Short and Long-Run Determinants of Inflation in Saudi Arabia: A Cointegration Analysis
}

\author{
Saad Mohammed Alnefaee ${ }^{1}$ \\ ${ }^{1}$ Saudi Electronic University, Jeddah, Saudi Arabia \\ Correspondence: Saad Alnefaee, Saudi Electronic University, Jeddah, Saudi Arabia. E-mail: S.alnafaiei@Seu.edu.sa
}

Received: July 30, 2018

Accepted: August 27, 2018

Online Published: September 2, 2018

doi:10.5430/ijfr.v9n4p35

URL: https://doi.org/10.5430/ijfr.v9n4p35

\begin{abstract}
This paper investigates the short and long-run determinants of inflation in Saudi Arabia for the period of 1987-2017. To achieve this objective, the Johansen and Julius cointegration procedure and Vector Error Correction Model (VECM) were conducted to examine the existence of the short and long-run relationships between inflation, the money supply, domestic demand, the exchange rate and oil prices. The results reveal that inflation, in the long-run, is positively influenced by the money supply, domestic demand, and oil prices. It is negatively influenced by the exchange rate. Inflation is also highly influenced by domestic factors in the short-run (e.g., money supply, domestic demand). The Granger causality results indicate a bi-directional causality between the money supply and inflation. The unidirectional causality goes from the domestic demand and the oil prices to the price level. The Impulse Response Analysis illustrates that shocks associated with the money supply, domestic demand and oil prices have a positive impact on inflation.
\end{abstract}

Keywords: inflation, cointegration, money supply, oil prices, granger causality, impulse response analysis

\section{Introduction}

Many academic and empirical studies have investigated the determinants of inflation in both developed and developing countries These studies considered inflation as a result of domestic and external factors (e.g., money supply, demand factors, supply factors, exchange rate, oil prices). Identifying the source of inflation for a specific country is important for designing economic policy. This study contributes to the literature by providing a better understanding of the factors influencing inflation in Saudi Arabia in both the short- and long-run. More specifically, the research objectives are: (a) to determine whether a stable long-run relationship exists between inflation and its explanatory variables, (b) to examine the size and the direction of the causality of the effects on inflation and (c) to check if shocks in the money supply, domestic demand, the exchange rate and oil prices can help forecast fluctuations in the price level.

Inflation in Saudi Arabia is measured by the General Authority for Statistics (GAS) in two ways: Cost of Living Index (CLI) and the Wholesale price Index (WPI). The CLI composed of 12 components which are food and beverages, tobacco, clothing and footwear, housing, water, electricity, gas and other fuels, furnishing equipment, health, transport, communication, recreation, restaurants, and miscellaneous goods and services. Data will be obtained from GAS survey, which is conducted monthly in sixteen cities in the Saudi Arabia. It is worth noting that the GAS survey makes no distinction between headline and core inflation by excluding food and energy prices from the CLI (Al-Hamidy, 2008). The mandate of the Saudi Arabian Monetary Authority (SAMA) is to maintain price and exchange rate stability. However, under a fixed exchange rate maintaining exchange rate stability is the first priority (Samba, 2010). Under a pegged currency and free capital mobility, the interest rate should not deviate much from the United States (US) interest rate. With the abandonment of the independent interest rate policy, SAMA has relied on macroprudential measures to ensure that domestic price stability and growth in domestic liquidity are broadly in line with the growth and availability of goods and services in the economy. Saudi Arabia has witnessed two waves of high inflation, (i.e., in 1970 and 2003). The second inflationary shock in 2003 occurred when government spending increased sharply due to high oil revenues. Inflation remained low during the 1990s, with an average annual growth rate of less than one percent. In 2003, the country experienced a dramatic increase in price level; it reached 2.2 percent in 2006, 4.1 percent in 2007 and 11.2 percent in 2008. It is worth noting that during the period of 2003 to 2010, the US dollar weakened dramatically against most other currencies, particularly the Euro. The sharp decline in 
oil prices in 2015 resulted in a substantial decrease in domestic demand, where inflation dropped to 2.2 percent. In January of 2018, the price level jumped to 3 percent following the introduction of various austerity measures to diversify the economy and to cement the government budget, including a 5 percent value added tax, fees on expats, and an excise tax, as well as a reduction in subsides on fuel and utilities.

\section{Selected Literature Review}

Several empirical studies have investigated the determinants of inflation in developing and developed countries. A few studies have investigated price inflation in Saudi Arabia; Al-Bassam (1999) examined the sources of inflation in Saudi Arabia using changes in the exchange rate and the US Dollar short term market interest rate, as external factors, and nominal money supply, real income (GDP) and the lagged price level as internal factors. The study found that growth in the money supply is an important source of inflation in Saudi Arabia. Darrat (1986) applied the monetarist model of inflation on three North African countries (i.e., Libya, Morocco, Tunisia) and concluded that foreign interest rates positively affected domestic inflation in each country in the study. Also found that growth in the money supply has a positive and significant impact on inflation in these countries. Nazer (2016) studied the impact of the money supply, oil prices, import values, US interest rate and real GDP on inflation in Saudi Arabia. The results reveal that the money supply and import values are positively related to inflation in Saudi Arabia. Ramady (2009) examined the external and internal determinants of inflation in Saudi Arabia using the money supply, the stock price index, oil prices, the US interest rate, and the exchange rate. The study found that the money supply, interest rate and domestic currency depreciation against other currencies are the main causes of inflation in Saudi Arabia. Al-Qenaie (2016) investigated the determinants of inflation in the following oil exporting countries: Algeria, Iran, Nigeria, Saudi Arabia and Venezuela the variables under investigation included population, government spending, oil prices, the money supply, the interest rate and the exchange rate. The study found that the determinants of inflation in Saudi Arabia include government expenditures and oil prices. Inflation in Iran was found to be associated with a high exchange rate and the interest rate. In Algeria and Nigeria the exchange rate determines inflation, while in Venezuela a high interest rate, growth of money, oil prices and the population are associated with an increase in inflation. Altowaijri (2011) examined the factors affecting inflation in Saudi Arabia using the money supply, the interest rate, foreign prices and the exchange rate. The study found that foreign prices and the exchange rate are the main source of inflation in Saudi Arabia. Hassan (2008) used cointegration and VECM to estimate the factors that affect inflation in Saudi Arabia using several variables, including the nominal effective exchange rate, the price level in trading partners, the money supply, GDP, and oil prices. The study found that the trading partners price level plays a dominant role in the long-run and domestic factors play a short-run role. Almounsor (2010) used the VECM to estimate inflation dynamics in Yemen. The study suggested that inflation in Yemen is driven by international price shocks, exchange rate depreciation, domestic demand and monetary shocks.

\section{Methods}

The following model examines the short and long run determinants of inflation in Saudi Arabia during the period of 1987-2017, where it, relates inflation to the money supply, non-oil GDP, the nominal effective exchange rate and oil prices. Due to limited quarterly data on GDP, we are using annual series data. The money supply, non-oil GDP, and Cost of Living Index (CLI) data were obtained from various issues of the SAMA annual report. The oil prices and exchange rate data were obtained from the International Financial Statistics (IFS) published by the International Monetary Fund.

$\mathrm{LCPI}=f(\mathrm{LM}+\mathrm{LY}+\mathrm{ER}+\mathrm{oil}+\mathrm{Ut})$ with $\frac{\partial L c p i}{\partial L m}>0, \frac{\partial L c p i}{\partial L y}>0, \frac{\partial L c p i}{\partial o i l}>0, \frac{\partial L c p i}{\partial E R}<0$ or $>0$

where

LCPI $=$ Cost of Living Index

LY $=$ Non-oil GDP as a proxy for domestic demand

$\mathrm{LM}=\mathrm{M} 3$ as a proxy for the money supply

Oil= Oil prices

$E R=$ Nominal effective exchange rate

$\mathrm{Ut}=$ The residual term

All variables are in log form, except for oil prices and ER 
Inflation is expected to be positively related to an excess money supply, aggregate demand and oil prices. The exchange rate relationship could be positive or negative.

\subsection{Stationarity Test}

Stock and Watson (1989) state that when a model consists of non-stationary variables the standard statistical tests would not have a standard distribution. To address this problem, Augmented Dickey-Fuller test (1981) can be estimated. The results in Table 1 illustrate that all series are non-stationary in levels, but stationary in their first differences; they are also integrated of order one.

Next step is to examine the presence of the long-run relationships among the variables to determine the optimal lag level. This will be accomplished using the Schwarz Bayesian Criterion (SBC) and the Akaike information Criterion (AIC).

Table 1. Test of time series stationarity in the level and the first difference

\begin{tabular}{lll}
\hline Variables & Dickey- Fuller (level) & Dickey- Fuller (first difference) \\
\hline CPI & $1.2^{*}$ & $8.01^{* * *}$ \\
\hline LY & $2.3^{* *}$ & $6.19^{* *}$ \\
\hline LM & $49^{* *}$ & $2.9^{* *}$ \\
\hline ER & $1.44^{*}$ & $3.55^{*}$ \\
\hline Oil_ & $2.6^{* *}$ & $3.2^{* *}$
\end{tabular}

Note: $*, * *, * * *$ statically significant at the 10,5 and, 1 percent levels respectively.

\subsection{Cointegration Method Results}

The number of cointegrating vectors was determined after it was found that all of the variables had the same order of integration. Two procedures were used to estimate the cointegration variables: the Engle and Granger' cointegration test procedure and the Johansen and Julius maximum likelihood procedure. The first test approach is limited to a bivariate analysis, while the other test is developed to test the multivariate series. We employ the latter technique, which is the most widely accepted test conducted for a cointegration analysis in the current literature. This test is used to examine the existence of a long-run relationship between inflation and a set of macroeconomic variables in Saudi Arabia. The Johansen and Julius maximum likelihood procedure is summarized in the following Error Correction form:

$$
\Delta \mathrm{y}_{\mathrm{t}}=\Gamma_{1} \Delta \mathrm{y}_{\mathrm{t}-1}+\Gamma_{\mathrm{kt}-1} \Delta \mathrm{y}_{\mathrm{t}-\mathrm{k}+1}+\Pi \mathrm{y}_{\mathrm{t}-\mathrm{k}}+\gamma+\varepsilon_{\mathrm{t}}
$$

where $\Delta \mathrm{y}_{\mathrm{t}}$ represents the vector of observations on all variables in the system at time t, the $\Gamma \mathrm{s}$ are estimable parameters in the short run, $\gamma$ is a constant vector, $\varepsilon_{t}$ is a vector of white noise, and the $\Pi$ matrix contains the cointegrating relationships. All variables must be non-stationary in levels. It is hypothesized that $\Pi=\alpha \beta$, where the cointegrating vectors are in the $\beta$ matrix and the $\alpha$ matrix, which describes the speed of adjustment for each variable change to return to their long-run equilibrium (Philips and Cutler, 1998). The presence of at least one cointegrating vector is sufficient for the existence of cointegration among the variables. The twin statistics of the trace and maximum eigenvalue are used to determine the number of cointegration vectors. The Johansen and Julius cointegration statistics are reported in Table 2.

Table 2. Results of the Johansen and Julius estimation procedure

\begin{tabular}{llll}
\hline 5 Percent Critical Value & Trace Statistics & Eigenvalue & Hypothesized No. of CE(s) \\
\hline 69.81 & 162.28 & 0.96 & None* \\
\hline 47.85 & 80.61 & 0.86 & At most $1^{*}$ \\
\hline 29.79 & 28.48 & 0.53 & At most $2^{*}$ \\
\hline 15.49 & 9.02 & 0.28 & At most $3^{*}$ \\
\hline 3.84 & 0.47 & 0.02 & At most $4^{*}$
\end{tabular}

*denotes rejection of the hypothesis at the 0.05 level. The Trace and Max-eigenvalue tests indicate 2 cointegrating equations. 
Table 2 presents the summary of the results of the cointegration analysis using the Johansen and Julius test. It is therefore evident that a long run relationship exists among the variables and moves together towards a stable long-run equilibrium. Consequently, the normalized cointegration equation is specified as follows:

$$
\begin{array}{ccccc}
\text { CPI }=7.4+0.9 & \mathrm{LY}+1.2 & \mathrm{LM}-0.9 \mathrm{ER}+ & 1.56 \text { Oil } \\
\text { t-ratio } & 4.0 & 2.1 & 2.0 & 1.9
\end{array}
$$

The signs on income, the money supply, and oil prices are positive, as expected. In the meanwhile, the sign on the exchange rate is negative.

\subsection{Results for Long-Run Elasticities}

1- There is a positive relationship between the money supply and inflation, which means that a 1 percent increase, on average, in M3, increases inflation by 1.2 percent. This finding is consistent with the quantity theory of money, where growth in the money supply is the primary determinant of inflation.

2- A positive significant relationship between the change in domestic demand and inflation is found. Empirically, a 1 percent increase in domestic demand adds 0.9 percent to the price level. This finding is in line with economic theory, where an increase in the aggregate demand results in excess demand of the goods and services available: this translates into demand pull inflation.

3- Equation (3) suggests a positive long-run relationship between inflation and oil prices. A one percent increase in oil prices pushes up inflation by 1.6 percent. In conjunction with the fact that Saudi Arabia is an oil-based economy, higher oil prices affect inflation in two ways. Firstly, higher oil revenue finances government spending on consumption and infrastructure projects. This places upward pressure on the price levels. Secondly, higher oil prices raise the international prices of imported food, capital equipment and raw materials, which could be interpreted as cost push inflation.

4- $\quad$ Although the Saudi Riyal is pegged against the US dollar, changes in the value of the dollar vis-à-vis other currencies do have a substantial inflationary effect. The negative long-run correlation between inflation and the exchange rate indicates that an appreciation in the US dollar makes imported goods from countries other than the US relatively cheaper, and vice versa. In addition, a one percent increase in the exchange rate (appreciation) results in a 0.9 percent decline in the price level.

\subsection{Granger Causality}

After proving the existence of a long-run equilibrium among the variables, a Granger causality test can be conducted. As Engel and Granger (1987) pointed out, if two variables are cointegrated, then a Granger causality must exist in at least one direction. The following standard Granger causality involves estimating the following equations:

$$
\begin{array}{ll}
\mathrm{Y}_{\mathrm{t}}=\sum & \alpha_{\mathrm{i}} \mathrm{Y}_{\mathrm{t}-\mathrm{i}}+\sum \\
\mathrm{X}_{\mathrm{t}}=\sum & \lambda_{\mathrm{i}} \mathrm{X}_{\mathrm{t}-\mathrm{i}}+\sum \mathrm{X}_{\mathrm{t}-\mathrm{j}}+\mu_{1 \mathrm{t}} \\
\delta_{\mathrm{j}} \mathrm{Y}_{\mathrm{t}-\mathrm{j}}+\mu_{2 \mathrm{t}}
\end{array}
$$

Assuming $\mu_{1 \mathrm{t}}$ and $\mu_{2 \mathrm{t}}$ are uncorrelated, t denotes the time period, $p$ lag length, and $\alpha, \beta, \lambda$, and $\delta$ are the coefficients to be estimated. Gujarati (1995) stated that four possible outcomes of causality can be distinguished.

First, the unidirectional causality from $X_{t}$ to $Y_{t}$, if the null hypothesis of $\beta_{j}=0$, is rejected; $\left(H_{0}: \sum \sum \beta_{j}=0\right)$.

Second, the unidirectional causality from $\mathrm{Y}_{\mathrm{t}}$ to $\mathrm{X}_{\mathrm{t}}$, if the null hypothesis of $\delta_{\mathrm{j}}=0$, is rejected, $\left(\mathrm{H}_{0}: \sum \delta_{\mathrm{j}}=0\right.$,).

Third, there is bi-directional causality if both coefficients are not significantly equal to zero.

Fourth, if $X_{t}$ and $Y_{t}$ are causally independent, all the coefficients of $X_{t}$ and $Y_{t}$ in Equations (3.1) and (3.2) are statistically insignificant. Both may grow, or move together, but neither influences the other.

Table 3. Two sets of lag causality test results

\begin{tabular}{lll}
\hline Causality Direction & F-test & Probability \\
\hline LM does not GC CPI & 3.39 & 0.051 \\
\hline CPI does not GC LM & 6.81 & 0.005 \\
\hline LY does not GC CPI & 0.36 & 0.701 \\
\hline Ly does not GC LM & 4.14 & 0.030 \\
\hline
\end{tabular}




\begin{tabular}{lll}
\hline LM does not GC LY & 0.480 & 0.630 \\
\hline ER does not GC CPI & 1.5 & 0.241 \\
\hline Oil does not GC CPI & 3.8 & 0.037 \\
\hline Oil does not GC LM & 3.01 & 0.061 \\
\hline
\end{tabular}

The results in Table 3 illustrate a bi directional causality relationship between the money supply and inflation. Growth in the money supply strongly Granger causes inflation; this finding is consistent with the economic theory where inflation is a monetary phenomenon (Friedman, 1963). In regard to the unidirectional causality between domestic demand and inflation, this finding supports the economic theory, where an increase in the domestic demand induces the consumption expenditure. This leads to an increase in the price level (demand pull inflation). A further unidirectional causality from the oil price to inflation supports the argument that higher oil prices increase aggregate wealth and demand. The results also suggest that the exchange rate is independent of changes in the inflation.

\subsection{Vector Error Correction Model Results}

The Vector Error Correction Model (VECM) is a short dynamic model. The deviation from the equilibrium in the short run can be captured through a VECM. In general, the following mathematical form generates a VECM:

$$
\Delta \mathrm{Y}_{\mathrm{t}}=\theta_{0}+\sum \alpha_{\mathrm{i}} \Delta \mathrm{X}_{\mathrm{t}-\mathrm{i}}+\sum \beta_{\mathrm{i}} \Delta \mathrm{Y}_{\mathrm{t}-\mathrm{i}}+\varphi_{1} \varepsilon_{\mathrm{t}-1}+\mu_{1 \mathrm{t}}
$$

The term $\varphi_{1} \varepsilon_{t-1}$ in Equation (4) represents the correction term that captures the deviation of the relationship among the variables from the long-run equilibrium and the short-run parameters. The regression result is presented in Table 4. The results reveal the adjustment coefficients for the set of variables that determines inflation in Saudi Arabia.

Table 4. Adjustment coefficients for the variables

\begin{tabular}{llllll}
\hline & $\mathrm{D}(\mathrm{CPI})$ & $\mathrm{D}(\mathrm{LM})$ & $\mathrm{D}(\mathrm{LY})$ & $\mathrm{D}(\mathrm{ER})$ & $\mathrm{D}(\mathrm{Oil})$ \\
\hline$\varepsilon \mathrm{t}-1$ & $-0.57^{*}$ & $-0.0020^{*}$ & 0.021 & -0.953 & -0.228 \\
\hline $\mathrm{D}(\mathrm{CPI}(-1))$ & $0.430^{*}$ & 0.003 & -0.226 & 0.688 & 1.420 \\
\hline $\mathrm{D}(\mathrm{CPI}(-2))$ & $0.162^{*}$ & -0.0026 & 0.010 & -1.167 & 1.585 \\
\hline $\mathrm{D}(\mathrm{LM}(-1))$ & $9.69^{*}$ & $-0.706^{*}$ & -56.32 & 20.820 & 70.10 \\
\hline $\mathrm{D}(\mathrm{LM}(-2))$ & 9.70 & -0.252 & -29.67 & 27.050 & 45.43 \\
\hline $\mathrm{D}(\mathrm{LY}(-1))$ & $0.190^{*}$ & $-0.003^{*}$ & -0.710 & -0.002 & 0.637 \\
\hline $\mathrm{D}(\mathrm{LY}(-2))$ & -0.012 & $-0.001^{*}$ & -0.501 & 0.030 & -0.045 \\
\hline $\mathrm{D}(\mathrm{ER}(-1)$ & 0.039 & 0.002 & 0.261 & 0.504 & 0.430 \\
\hline $\mathrm{D}(\mathrm{ER}(-2)$ & 0.0900 & $0.002^{*}$ & 0.643 & -0.302 & -0.015 \\
\hline $\mathrm{D}($ Oil(-1) & 0.101 & 0.001 & -0.120 & -0.529 & 0.633 \\
\hline $\mathrm{D}($ Oil(-2) & -0.022 & 0.002 & -0.365 & -0.179 & -0.102 \\
\hline $\mathrm{R}$-squared & 0.70 & 0.83 & 0.44 & 0.30 & 0.91 \\
\hline
\end{tabular}

The error correction term, or the speed of adjustment, is negative and significant (-0.57). This implies that if the price level in a previous period was higher than what the long-run relationship predicts by 1 percent, then there will be an adjustment to reduce the price level by 0.57 to restore the long-run equilibrium. The main important source of short-run inflation is the money supply, where a one percent increase in the money supply pushes up inflation by 9 percent. Another source of short-term inflation is domestic demand, which implies that a one percent increase in income adds to the price level by 0.2 percent. The short-run elasticity for income and the money supply are positive, significant and larger in magnitude than the long run. A possible explanation is that inflation in Saudi Arabia is influenced by the domestic factor in the short-run. This finding is consistent with that of Hassan (2008). 
Table 5. Variance decomposition

\begin{tabular}{lllllll}
\hline Period & S.E. & $\Delta$ CPI & $\Delta \mathrm{LM}$ & $\Delta \mathrm{LY}$ & $\Delta$ ER & $\Delta$ Oil \\
\hline 1 & 1.889 & 100 & 0 & 0 & 0.00 & 0.00 \\
\hline 2 & 3.251 & 98.68 & 0.30 & 0.61 & 0.08 & 0.32 \\
\hline 3 & 4.981 & 97.18 & 1.90 & 0.44 & 0.16 & 0.36 \\
\hline 4 & 6.535 & 94.66 & 4.31 & 0.45 & 0.12 & 0.45 \\
\hline 5 & 8.171 & 87.24 & 9.61 & 2.50 & 0.10 & 0.55 \\
\hline 6 & 9.824 & 78.91 & 14.8 & 5.40 & 0.13 & 0.65 \\
\hline 7 & 11.477 & 70.12 & 19.5 & 9.40 & 0.24 & 0.74 \\
\hline 8 & 13.100 & 61.92 & 23.4 & 13.60 & 0.40 & 0.78 \\
\hline 9 & 14.672 & 54.71 & 26.4 & 17.50 & 0.58 & 0.80 \\
\hline 10 & 16.115 & 49.02 & 28.6 & 21.01 & 0.75 & 0.80 \\
\hline
\end{tabular}

\subsection{Variance Decomposition}

The Variance Decomposition (VD) explains the short-run response of inflation to shocks in the money supply, domestic demand, the exchange rate and oil prices. Table 6 reports the results of the VD of the price level in Saudi Arabia for different time periods (i.e., one to 10 times periods). The results reveal that inflation is mostly explained by its own fluctuations. This is followed by money supply and domestic demand shocks. Money supply shocks account for about 10 percent of the fluctuation in the price level in the fifth period. Innovations in the domestic demand account for 3 percent. During the tenth period, money supply shocks were found to account for 29 percent of the variation in the price level and domestic demand shocks accounted for 21 percent. Therefore, the money supply and domestic demand become the most significant explanatory factors after inflation in the short run.

\subsection{Impulse Response Analysis}

To further investigate the relationship between inflation and the explanatory variables over time, the Impulse Response Function (IRF) will be constructed with two lags as recommended by the AIC and the Schwartz order selection criteria. Figure 1, illustrates that a positive money supply shock results in a gradual increase in the price level. Surprisingly, shocks to the domestic demand affect inflation negatively in the first three periods before the shocks add to inflation. Despite the positive response of inflation to shocks in the oil prices, the magnitude of the response is smaller than the monetary shocks. In terms of the response of inflation to shocks from the exchange rate, the results indicate that the appreciation has a positive influence on inflation. This finding is contrary to the empirical relationship between the exchange rate and the price level.

\section{Conclusions}

The primary objective of this paper was to identify the short-and long-run determinants of inflation in Saudi Arabia for the period of 1987-2017. This was accomplished by applying the Johansen and Julius procedure of cointegration. The results indicate that the long-run equilibrium relationship among the variables exists and that domestic demand, the money supply and oil prices have a positive impact on inflation in the long run, while the exchange rate has a negative effect. The short run dynamics were conducted by using the Vector Error Correction Model (VECM). The results reveal that domestic demand and the money supply are positive and significant; their coefficients are larger in magnitude than the long-run.

The causality test results indicate that there is a bi-directional relationship between inflation and growth in the money supply and a unidirectional causality reported from the domestic demand and oil prices to inflation. The impulse response analysis indicates that the money supply, domestic demand and oil prices have a positive effect on inflation. Therefore, changes in the money supply, domestic demand and oil prices can be used as a good predictor of future inflation.

The findings suggest that close coordination between monetary and fiscal policies is needed to help alleviate inflationary pressures, especially in the context of the current implementation of economic reforms that aim to gradually sustain fiscal consolidation. The exchange rate pass through to inflation is significant and suggests additional exchange rate flexibility in the period ahead, as the economy becomes less dependent on oil, and if the US 
and Saudi business cycles continues to diverge. Exchange rate flexibility would also allow for greater monetary independence to control inflation. It is hoped that this study stimulates future research to use quarterly data that incorporates wage trends to test if wages push inflation in Saudi Arabia.
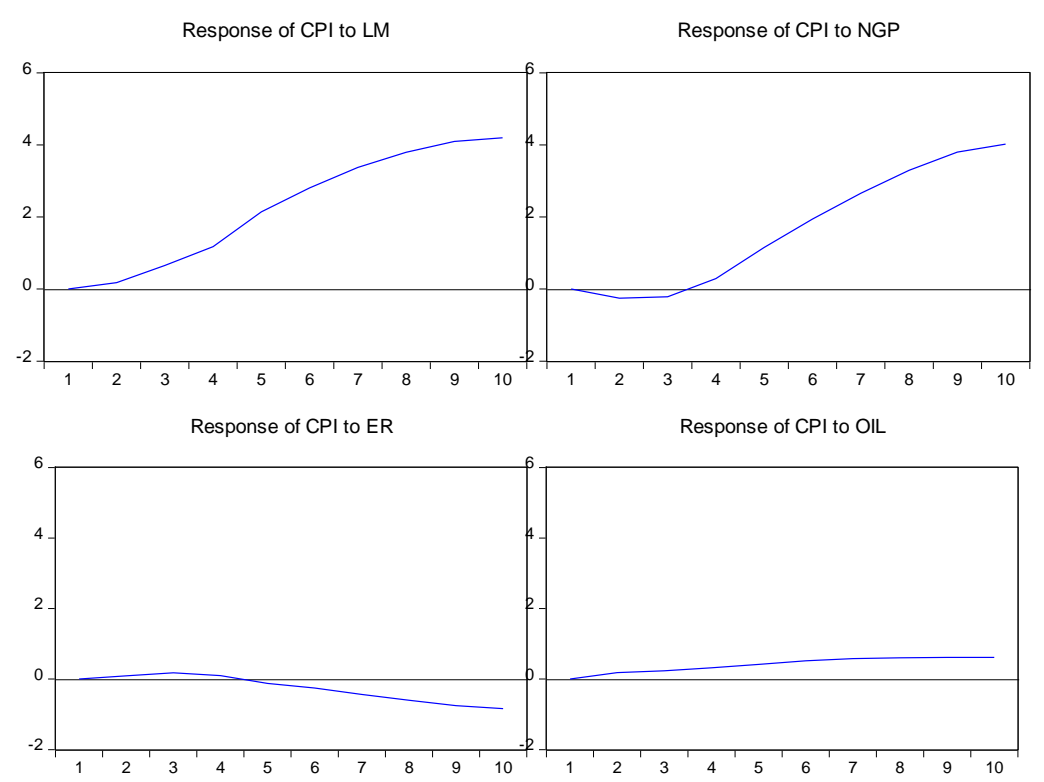

Figure 1. The impulse response of inflation to structural shocks

\section{References}

Al-Bassam, K. (1999). Domestic Sources of Inflation in Saudi Arabia: An Empirical Study. Journal of KAU, Econ \& Adm., 13(1), 3-30. https://doi.org/10.4197/Eco.13-1.1

Al-Hamidy, A. (2009). Monetary Policy and the Measurement of Inflation: Prices, Wages and Expectation. Bank of Settlement Papers, no. 49.

Almounsor, A. (2010). The Dynamic of Inflation in Yemen. IMF Selected Papers. Washington .D.C. https://doi.org/10.5089/9781455201273.001

Al-Qenaie, J., \& Al-Shammari, N. (2015). Causes of Inflation A cross Main Oil Exporting Countries. Unpublished Paper.

Altowaijri, H. (2011). Determinants of Inflation in Saudi Arabia. World Review of Business Research, 1, 109-114.

Darrat, A. (1986). Money, Inflation, and Causality in the North African Countries: An Empirical Investigation. Journal of Macroeconomics, 89(1), 87-103. https://doi.org/10.1016/0164-0704(86)90035-2

Dickey D., \& Fuller, W. (1981). Likelihood Ratio Statistics for Autoregressive Time Series with A Unit Root. Econometrica, 49(4), 1057-1072. https://doi.org/10.2307/1912517

Enders, W. (1995). Applied Econometrics Time Serie (1st ed.). John Wiley and Sons, New York.

Engle, R., \& Granger, C. (1987). Cointegration and Error Correction: Representation, Estimation and Testing. Econometrica, 55(2), 251-276. https://doi.org/10.2307/1913236

Friedman, M. (1963). Inflation: Causes and Consequences. New York: Asia Publishing House.

Gujarati, D. N. (1995). Basic Econometrics (3rd ed.). New York: McGraw Hill.

Hasan, M. (2008). Understanding the Inflation Process in Saudi Arabia. IMF Selected Papers, Washington .D.C.

International Monetary Fund. (2017). International Financial Statistics (IFS). Washington, D.C.

Johansen, S., \& Julius, K. (1990). Maximum Likelihood Estimation and Inference on Cointegration with Applications to the Demand for Money. Oxford Bulletin of Economics and Statistics, 52, 169-210. https://doi.org/10.1111/j.1468-0084.1990.mp52002003.x 
Nazer, Y. (2016). Causes of Inflation in Saudi Arabia. The Business and Management Review, 7(3), $147-154$.

Nelson, C., \& Plosser, C. (1982). Trends and Random Walks in Macroeconomic Time Series: Some Evidence and Implications. Journal of Monetary Economics, 10(2), 139-162. https://doi.org/10.1016/0304-3932(82)90012-5

Philips, J., \& Cutler, H. (1998). Domestic Exchange Rates and Regional Economic Growth in the United States, Evidence from cointegration analysis. Journal of Economic History, 58(4), 1010-1026. https://doi.org/10.1017/S0022050700021707

Ramady, M. (2009). External and Internal Determinants of Inflation: A Case study of Saudi Arabia. Middle East Journal of Economics and Finance, 2(1), 25-38.

Saudi American Bank. (2010, April). Inflation in Saudi Arabia: Drivers, Trends, and Outlook. Report Series.

Saudi Arabian Monetary Authority. (2017). Annual Report. Various Issues.

Stock, J., \& Watson, M. (1989). Interpreting Evidence on Money, Income Causality. Journal of Econometrics, 161-182. https://doi.org/10.1016/0304-4076(89)90035-3 